International Research Journal of Management, IT \& Social Sciences
Available online at https://sloap.org/journals/index.php/irjmis/
Vol. 6 No. 4, July 2019, pages: 17 30
ISSN: 2395-7492
https://doi.org/10.21744/irjmis.v6n4.649

\title{
Influence of Industry Type, Profitability and Size on Corporate Social Responsibility Reports Isomorphism Stage in Indonesia
}

\author{
Ni Putu Ratih Kesuma Yani ${ }^{\text {a }}$ \\ Herkulanus Bambang Suprasto ${ }^{b}$ \\ Maria Mediatrix Ratna Sari ${ }^{\mathrm{c}}$ \\ I Gusti Ayu Made Asri Dwija Putri ${ }^{\mathrm{d}}$
}

Article history:

Received: 27 March 2019

Accepted: 31 May 2019

Published: 7 June 2019

\section{Keywords:}

corporate social; institutional theory; isomorphism; responsibility report; sustainability report;

\begin{abstract}
This research examines the influence of industry type, profitability, and size on corporate social responsibility reporting in Indonesian into three stages of isomorphism. The method purposive sampling of companies listed in Kompas 100 Index from 2009 to 2016 resulting 327 coercive, 317 normative and 217 mimetic samples. Data were analyzed using binary logistic regression. The results show that only size affected on firm's tendency to adopted corporate social responsibility reporting by publishing sustainability report in coercive isomorphism stage. Meanwhile industry type, profitability, and size affected on firm's tendency to adopted corporate social reporting by publishing sustainability report in normative isomorphism stage. The result also showed that industry type and size affected on a firm's tendency to adopted corporate social responsibility reporting by publishing a sustainability report in mimetic isomorphism stage. The only size is constantly influenced by corporate social responsibility reporting. We can conclude that size as the most important factor to firm considers in issuing a sustainability report in Indonesia.
\end{abstract}

2395-7492@ Copyright 2019. The Author. This is an open-access article under the CC BY-SA license (https://creativecommons.org/licenses/by-sa/4.0/) All rights reserved.

\section{Author correspondence:}

Yani, N.P.R.K.

Faculty of Economics and Business, Udayana University, Denpasar, Indonesia

Jalan P.B. Sudirman, Dangin Puri Kelod, Denpasar, Bali 80234

Email address: ratih.kesuma1412@gmail.com

\footnotetext{
${ }^{a}$ Faculty of Economics and Business, Udayana University, Denpasar, Indonesia

${ }^{\mathrm{b}}$ Faculty of Economics and Business, Udayana University, Denpasar, Indonesia

${ }^{\mathrm{c}}$ Faculty of Economics and Business, Udayana University, Denpasar, Indonesia

${ }^{\mathrm{d}}$ Faculty of Economics and Business, Udayana University, Denpasar, Indonesia
} 


\section{Introduction}

Corporate social responsibility (CSR) reporting is one of an important issue related to the firm's sustainability. Corporate social responsibility defined as the obligation of every firm to the community as the impact of their operational activity towards the firm's sustainability in the future (Kastutisari \& Dewi, 2014). By actively participating in social responsibility, manage their social issues effectively and proactive to develop their social responsibility specifically the firm will gain legitimacy (Beddewela \& Fairbrass, 2016). Legitimacy is community acceptance of the firm's operational business. The firms need to gain and manage their legitimacy (Suchman, 1995) because of legitimacy influences a firm's sustainability (Ismail \& Haddaw, 2014). CSR is a mechanism to motivate stakeholder and to manage social perception about the firm's role and utility to the community outside the main function of production and marketing of its products (H. Wang, 2016).

Implementation of CSR in Indonesia regulated by several regulations like Indonesian's Constitution Number 40 Years 2007 about limited liability firm stated that firm is running their business activity and/or related to the natural resource are required to implement social responsibility and environment (Indonesian Constitution No. 40, 2007). This constitution statement then expanded by Indonesian's Constitute Number 32 Years 2009 that state everyone who has business activity obligated to (1) give information related to social responsibility correctly, accurately, free-for-all and timely; (2) support natural sustainability function; and (3) obey the regulation related environmental quality standards and/or environmental damage's criteria. In 2012, the Indonesian government made more improvement about how a firm should planning their CSR by issuing Government Regulation Number 47 Years 2012. The firm should plan their CSR activities andreport on general meeting of shareholder(Indonesian Government Regulation No. 47, 2012). The regulation aims to create more balance situation between management and stakeholder relating a firm's CSR activity. Regulation of Financial Services Authority Number 29 /POJK.04/2016 article $4 \mathrm{~h}$ also stated that in the firm required to disclose their social responsibility in the annual report (Indonesian Financial Service, 2016a). The government regulations are directing the CSR disclosure into the isomorphic state.

Even there are several regulations for CSR in Indonesia required the firm to disclose their CSR and reporting but implement in in sustainability report is still voluntary. Based survey of Financial Service Authority at the end of 2016 there are 49 of 539 firms that issue their social responsibility in sustainability report (Indonesian Financial Service, 2016b). The trend of reporting increases since 2011 there are just 25 of 438 firms that issue sustainability report (Kontan.co.id, 2011). This is the low amount but it increased slowly every year. The firm seems aware of the reporting issues because they've seen the potential of CSR's benefits is more than it costs (Shabana, Buchholtz, \& Carroll, 2016). The firm can use the sustainability report to decrease stakeholder pressures and communicating their CSR policies and practices (Frumkin \& Galaskiewicz, 2004). Survey of KPMG, (2015) found that Indonesia is one of eight countries with a corporate responsibility reporting rate of 90 percent or above have a mandatory requirement. This makes the firms in Indonesia tend to be sensitive in changes of regulation.

For more than 13 years, researchers in Indonesia have explored determinants of CSR reporting such as industry type (Anggraini, 2006; Apriyanti \& Budiasih, 2016; Cahaya, 2012; Karina \& Yuyetta, 2013; Marfuah \& Cahyono, 2011; Pratiwi \& Sari, 2016; Purwanto, 2011; Sembiring, 2006; Tan et al., 2016), size (Anggraini, 2006; Ni Made Winda Apriyanti \& Budiasih, 2016; Cahaya, 2012; Karina \& Yuyetta, 2013; Marfuah \& Cahyono, 2011; Pratiwi \& Sari, 2016; Purwanto, 2011; Sembiring, 2006; Tan et al., 2016) and profitability (Apriyanti \& Budiasih, 2016; Aulia \& Agustina, 2015; Bawono \& Haryanto, 2015; Kamil \& Herusetya, 2012; Marfuah \& Cahyono, 2011; Sembiring, 2006; Sirait \& Bangun, 2013; Dewi et al., (2017); Wulansari \& Priyadi, 2015). But still, there's no research about how CSR in Indonesia developed influenced by institutional pressures i.e. government regulations. Therefor we want to conduct the CSR research-based institutional theory.

The transition of CSR is embedded from institutional changes in social concern growth and environmental limitation from stakeholder and regulation pressures (Roszkowska-Menkes \& Aluchna, 2017). Some of scholar drawn upon institutional theory into isomorphism concept to show how firm can adopt new form and procedure another firm in the same industry field to reduce institutional pressures (DiMaggio \& Powell, 1983; Donleavy, 2016; Frumkin \& Galaskiewicz, 2004; Martínez-Ferrero \& García-Sánchez, 2017; Nuryani et al., 2018; Shabana et al., 2016). In this case, the institutional pressure in Indonesia directing the firms into the isomorphic state. This research is trying to capture the role or influence of government on the institutionalization of CSR reporting that can't be captured by (Shabana et al., 2016).

Isomorphism defined broadly as the propensity of organization in a population to resemble other organization that runs under similar environmental conditions (Donleavy, 2016:95). (DiMaggio \& Powell, 1983; Aghara et al., 2018) identifies three mechanisms of isomorphism such as coercive (pressure to close the gap between expectation and 
performance), mimetic (pressure of uncertainty) and normative (pressure of professionalization and normative environment). We use Shabana et al., (2016) approached that explain isomorphism of DiMaggio \& Powell (1983) into three stages of isomorphism model. This model explains how isomorphism has shaped CSR reporting towards homogenization. This three-stage model of CSR reporting provides a greater understanding of past diffusion and how future social innovations can be most effectively disseminated. Shabana et al., (2016) model are presented in Figure 1 explain that the adoption of CSR reporting depicting at three stages process that illustrated the early adoption (the regulation was issued), mainstreaming, and imitative diffusion. Every stage has a different dominant isomorphic mechanism that motivating the firm participation in reporting CSR.

Figure 1

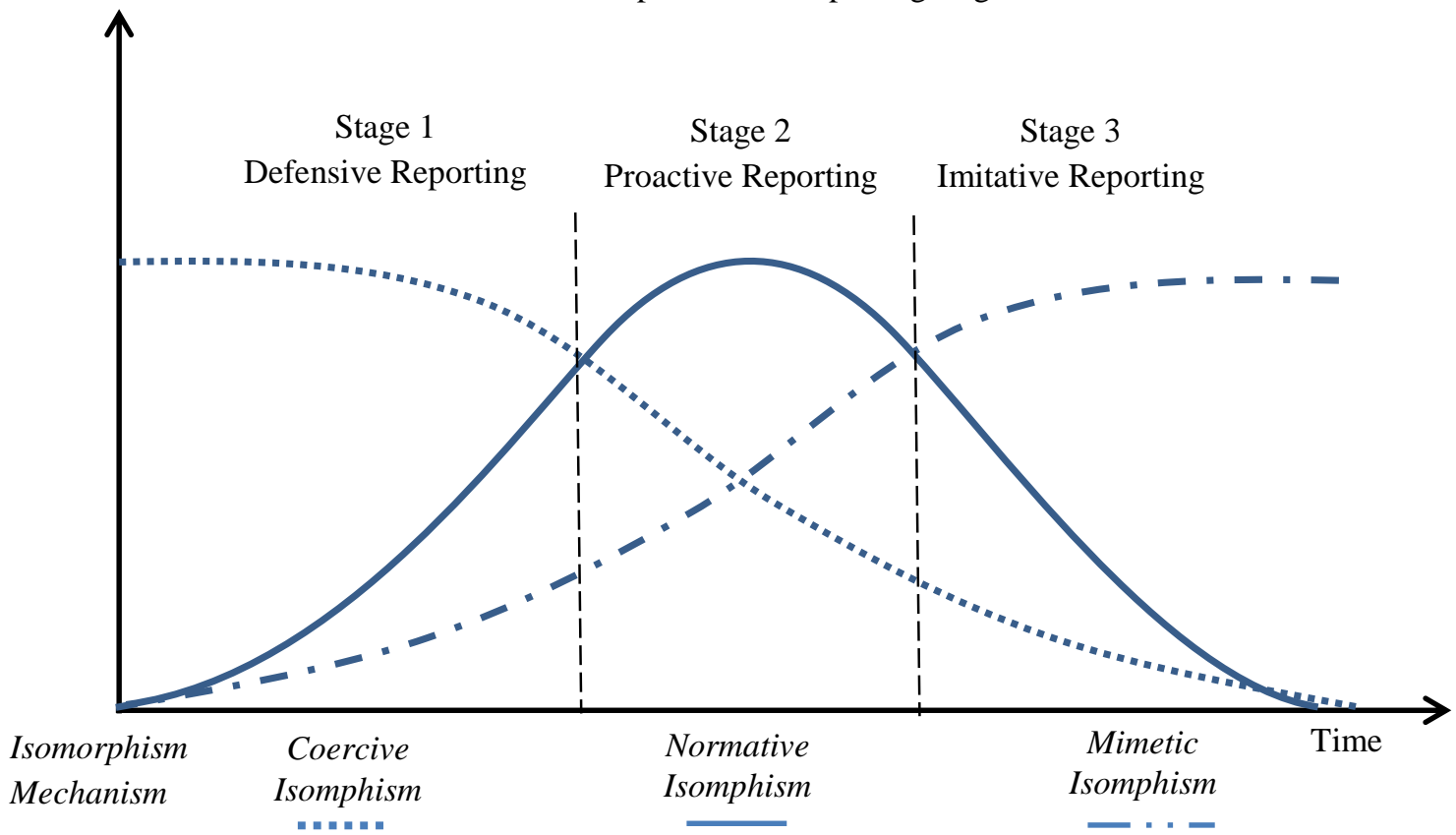

Source: Shabana et al., (2016)

\section{Literature Review \\ Institutional Theory}

The institutional theory explained how the firm could adopt form and procedure another firm in order to maintain their legitimation. Institutional theory is a theoretical framework for analyzing social phenomena (especially organizational) and viewing the social world as an institution that has significant rules, practices, and structures from a set of conditions in an action that continues to exist (Lawrence \& Shadnam, 2007; Yanti et al., 2019). Legitimation is one of condition that assumed by institutional theory as a general perception for an entity to acts by the system of the socially formed norm, values, trust and belief (Suchman, 1995).

Institutional theory in the general context of corporate social responsibility predicts how structures and organizational practice tend to be similar to conform with what is called 'normal' in their environment (Donleavy, 2016). This theory explains how the firm implements their social responsibility practice to gain legitimation and meets the various parties expectation according to the norms accepted in the industry because of stakeholder and competitor pressures (Aminu, Harashid, \& Azlan, 2016). Institutional pressures could affect a firm's policy in CSR disclosure and assurance (Fisher, 2016).

Yani, N. P. R. K., Suprasto, H. B., Sari, M. M. R., \& Putri, I. G. A. M. A. D. (2019). Influence of industry type, profitability and size on corporate social responsibility reports isomorphism stage in Indonesia. International Research Journal of Management, IT and Social Sciences, 6(4), 17-30. https://doi.org/10.21744/irjmis.v6n4.649 


\section{Corporate Social Responsibility Reporting}

Concept of corporate social responsibility associating firm's social issues commitment and their business environment with stakeholder to creating supported social responsibility by the norm and international regulation, industry standard and formal demand of company's customer (Misztal \& Jasiulewicz-Kaczmarek, 2014; Suardana et al., 2018). Regulation of Financial Services Authority Number 29/POJK.04/2016 stated that every public firm or listed firm in Indonesian Stock Exchange required to disclose their social responsibility in the annual report (Indonesian Financial Service, 2016a). Government Regulation Number 47 Years 2012; and Indonesian's Constitute Number 32 Years 2009 also required the firm to disclose their CSR through CSR report or sustainability report. The reporting practice in Indonesia developed following the government's regulations such as how implementing CSR report, what kinds of aspect that should be disclosed, and also the standard of CSR reporting.

There are four main reason firm implements social responsibility that reduces cost and risk; gain competitive advantage; development of reputation and legitimacy; and gain win-win outcomes through value creation (Matten \& Moon, 2008). Implementation of corporate social responsibility consistently in the long-term could increase legitimacy (Susanto \& Subekti, 2013; Manteiro \& Kabu, 2019). Disclosing CSR through annual report also can increase the firm value (Maulana \& Yuyetta, 2014). That's because the firm fulfills the institutional expectation to be responsible for environmental impact and social development.

During 2011 - 2013 the disclosure of social responsibility and environment in Indonesia has an increase (Winata, 2015; Linzan et al., 2018). At the end of 2016, there are 49 or 9 percent firms that listed in Indonesian Stock Exchange discloses their social responsibility in sustainability report. This shows that the firms in Indonesia are aware of social responsibility issues. A sustainability report is a report that contains practice in measuring and disclosing social and environmental activity as a responsibility to internal and external stakeholder about organizational performance in realizing sustainable development goals. Stand-alone CSR report by issuing a sustainability report can increase a firm's reputation and accountability because the report contains integrated information social and environment more transparently, completely and accountability (Patten \& Zhao, 2014).

\section{Three Stage CSR Isomorphism Model}

Isomorphism defined broadly as the propensity of organization in a population to resemble other organization that runs under similar environmental conditions (Donleavy, 2016). Isomorphism caused by the institutional pressures such as government regulation, social norm, industry environment, etc. that push the firm to be similar in the form and relations. Isomorphism also defined as process trying to adapt in institutional norms and practices that stimulate organization imitating other organization do to socially acceptable or gain legitimacy (Aminu et al., 2016). The model presented (Figure 1) explains that the adoption of CSR reporting in Indonesia because of government regulations depicting at three stages process that illustrated the early adoption (the regulation was issued) called defensive reporting, mainstreaming called proactive reporting, and imitative reporting or imitative diffusion. Every stage has a different dominant isomorphic mechanism that motivating the firm participation in reporting CSR. This is because the firm need to maintain their sustainability business by adapting in every situation.

At the early adoption, the firm tends to disclose their CSR to meet the institutional expectation and obey to the regulation which is coercive. In the defensive reporting, the firm faces pressures to confirm the organization on which the firms depend (in this case government) and the society in general. It arises from coercive isomorphism that firm tends to disclose their CSR reporting to meet the expectation of government and industry regulation to gain legitimacy. The firms tend to disclose their CSR to maintain their business sustainability. The institutional theory explains that the government regulations as one of institutional pressure that could direct the firm in the isomorphic state. In Indonesia, the coercive mechanism arises because the government issued the Statute Number 40 Years 2007 and Number 32 Years 2009 about CSR reporting and implementation. Corporate social responsibility reporting become things that must be done to meets social expectation. The firm uses CSR disclosure as a defensive mechanism against negative perception on the impact of a firm's operational activity. The coercive pressure by government regulation aims to decreased number of un-responsible business activity (Roszkowska-Menkes \& Aluchna, 2017).

In the proactive reporting, the firm faces pressure to the normative sanction from the community if they don't disclose their CSR reporting. The regulation pressures will weakness as time goes by, the firm used to disclose their CSR in an annual report. After the Indonesian Government issued the Statute Number 40 Years 2007 and Number 32 Years 2009 about CSR reporting and implementation, then they issued Government Regulation Number 47 Years 2012 that more specific regulated limited company about their social responsibility disclosure and policy that could firm 
choose in the reporting practice. Normative isomorphism consists of adjusting the company's perspective especially environmental changes through communication and organizational development (Donleavy, 2016). The firm seeking opportunities to improve their image with disclose CSR in a better way or not just to fulfill the regulatory requirement. For example, they disclose their CSR in the sustainability report, take part in CSR Awards, voluntary participating in government social program, etc. In the proactive stage, the firms see potential opportunity to gain positive image from CSR implementation through issuing standalone CSR report called sustainability report.

The improvement of CSR reporting practice makes the potential reporter reach the threshold that makes them gain more benefit than their reporting cost. The firms adopt CSR practice under uncertainty business circumstances and market pressures to maximize shareholder's value (Roszkowska-Menkes \& Aluchna, 2017). In the imitative diffusion, the firm faces uncertainty how to be a good firm and they tend to pattern their firm similar with the other organization in the relevant environment that considered successful (DiMaggio \& Powell, 1983). The firm expects they will gain the same success as their firm's role and reduce the risk of failure practice. The mechanism underlying the imitative diffusion is a mimetic isomorphism. The practice of CSR reporting becomes generally accepted. The firm saw CSR as an opportunity to gain a competitive advantage if it programmed and reported correctly. In the mimetic isomorphism mechanism, the firm tends to imitate another firm that already gains success and advance (Donleavy, 2016).

\section{Hypotheses Development}

Industry type determined how intents firm disclose their social responsibility. The firm categorized as high-profile when their business activity directly affect the environment so the stakeholder gives more attention to their business activity, meanwhile low profile is the firm that their activity does not directly affect the environment. The Government Regulation Number 47 Years 2012 explain that the CSR activity and reporting must be discussed and planned in general meeting shareholder (RUPS) so implementation of CSR is effective and efficient. The high and low profile type will choose different approach in implementing their CSR. The industry type is related to industry sensitivity on the environment and affected on the tendencies of the firm to disclose CSR (Tan et al., 2016). High profile firm tends to disclose more social disclosure because the high-profile firm got more attention because of their sensitive impact on the environment. (Cahaya, 2012; Marfuah \& Cahyono, 2011; Purwanto, 2011; Sembiring, 2006; Shabana et al., 2016; J. Wang et al., 2013) found that the industry profile affected on CSR reporting. Pratiwi \& Sari (2016) and Apriyanti \& Budiasih (2016) found that industry type affected on CSR reporting. Hence:

H1: Industry type affected on CSR reporting

Stakeholder theory explained that the stakeholders give more attention to a firm with high profitability. Wulandari \& Suprasto (2015) state that investor appreciates CSR information as a positive determinant of earnings quality. The higher profit the firm tends to do more CSR activity (Sirait \& Bangun, 2013) and disclose their social information (Aulia \& Agustina, 2015). Profitability becomes one of the aspects considered in making CSR budgets in accordance with Government Regulation Number 47 Years 2012. Margaretha \& Rachmawati (2010) stated that the CSR implementation fund is relative and must consider in investment and budgeting. This aim to ensure that CSR implementation is proportional with the firm's profit. The firm with high profitability has a good prospect of financial sustainability. They tend to spend more for CSR to show that the firm in high financial position. Jannah \& Kurnia (2016) stated that profitability affected on CSR disclosure about shareholder trust that the firm responsible for social and sustainable. Sirait \& Bangun (2013); Apriyanti \& Budiasih, (2016); Aulia \& Agustina (2015) and Pratiwi \& Sari (2016) found that profitability affected on CSR reporting. Hence:

H2: Profitability affected on CSR reporting

The size of the firm frequently associated with the ability to produce and provide a fund to activity include CSR activity (Marfuah \& Cahyono, 2011). The larger firm the greater the ability the firm to bear the risk. Larger firm capable of affecting their economic and other environments garners more attention from the general public than the smaller firms (Shabana et al., 2016). The larger size of the firm they gain more attention from stakeholder and they have larger social responsibility (Sirait \& Bangun, 2013). Bawono \& Haryanto (2015); Hadjoh \& Sukartha (2013); Marfuah \& Cahyono (2011); Sembiring (2006); Tan et al., (2016); Widyastari \& Sari (2018); and Wulandari \& Suprasto (2015) found that the size affected on the CSR reporting. This result also supported by Kamil \& Herusetya (2012) that found the larger firm faces more institutional pressures than the small firm. This situation makes larger firm tend to disclose their CSR activity than the small firm (Andreas et al., 2015). Hence:

H3: Size affected on CSR reporting

Yani, N. P. R. K., Suprasto, H. B., Sari, M. M. R., \& Putri, I. G. A. M. A. D. (2019). Influence of industry type, profitability and size on corporate social responsibility reports isomorphism stage in Indonesia. International

Research Journal of Management, IT and Social Sciences, 6(4), 17-30. https://doi.org/10.21744/irjmis.v6n4.649 


\section{Materials and Methods}

Figure 2

Theoretical model

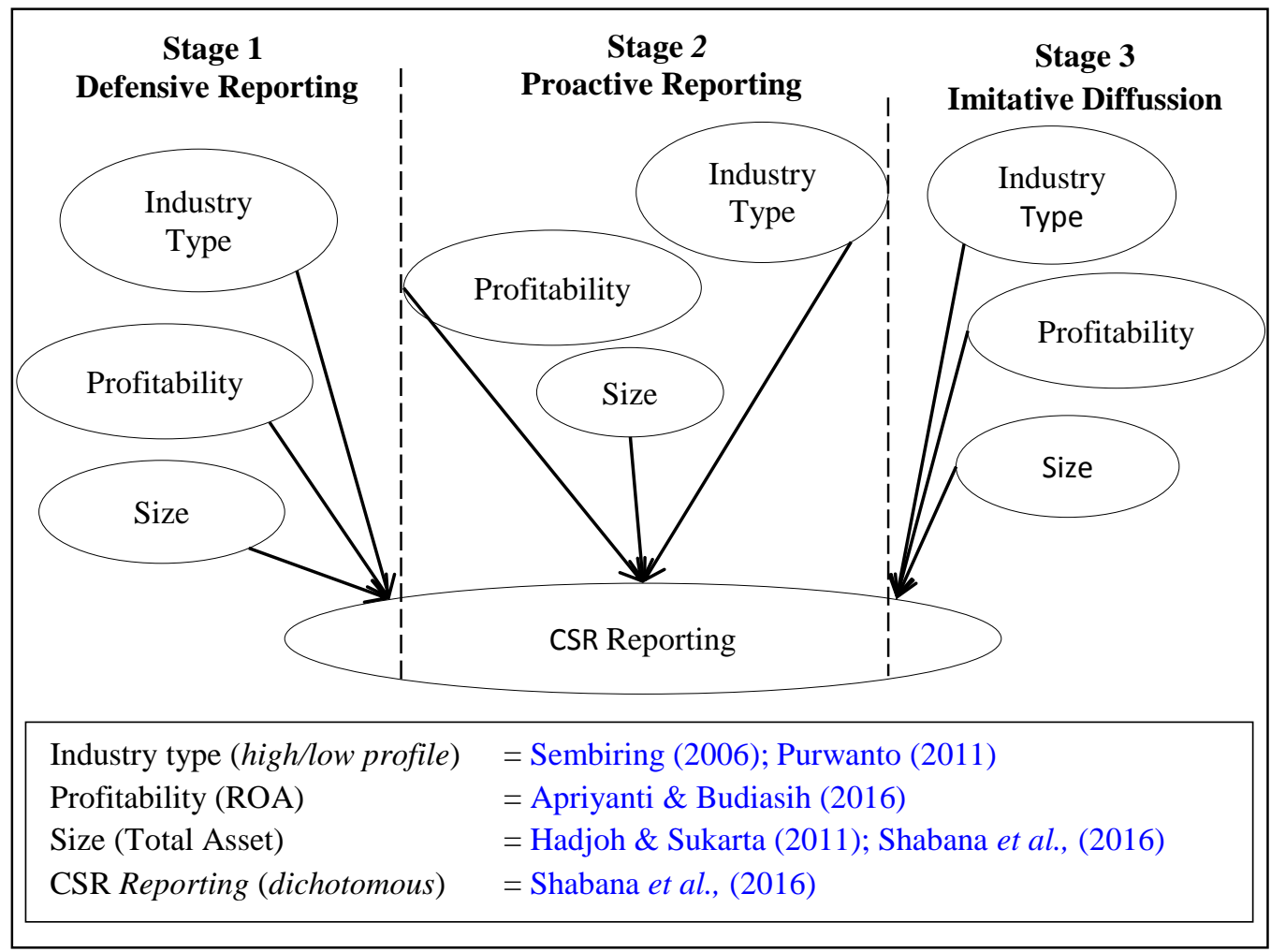

\section{Population and Sample}

The population in this study is firms listed in Indonesian Stock Exchange. The samples consist of the firms that appeared on the Kompas100 Index list in 2009 - 2016. The chosen year reflects the significant dates in the evolution of CSR reporting and regulation in Indonesia. The first rule is Indonesian's Constitution Number 40 Years 2007 , the second one is Indonesian's Constitute Number 32 Years 2009, and the third is Government Regulation Number 47 Years 2012. Thought the first rules regarding CSR reporting was an issue in 2007, but the scope of regulation limited to firms that their business impact the environment directly and state-owned enterprises so we use years 2009 to 2011 as the defensive reporting cut-off based in Indonesian's Constitute Number 32 Years 2009. The proactive reporting sample selected from 2012 to 2014 based Government Regulation Number 47 Years 2012. The imitative reporting sample selected in 2015 and 2016. Initially, 892 firms appeared on the Kompas100 Index's list in years 2009 - 2016. Thirty-one firms were eliminated because of no information about their CSR reporting activity and their annual report. The number of the final sample was 327 in defensive reporting, 317 in proactive reporting and 217 in mimetic reporting.

\section{The Measurement of Operational Variables}

a) Corporate Social Responsibility Reporting

Corporate social responsibility as a dependent variable measured in dichotomous scale by giving a score 1 (one) to a firm that discloses their CSR in a sustainability report and 0 for a firm that did not. This item used to measure CSR reporting that adopted from the research by (Shabana et al., 2016). The dependent variable lags 
the independent variables by one year. The dependent variables collected for defensive reporting are years 2019 -2012, proactive reporting 2013 - 2015, and mimetic reporting 2016 and 2017.

b) Industry Type

The industry type is the view of the community about the firm's characteristics related to their business sector, risk, employee and environment impact (Sembiring, 2006). This variable measured in dichotomous scale by giving a score 1 (one) to a firm that categorized as high-profile and 0 to a firm that categorized low-profile. This item adopted from research by Sembiring (2006) and Purwanto (2011).

c) Profitability

According to Apriyanti \& Budiasih (2016), the profitability in this research is measured by using the return on asset ratio. The return on asset is a comparison between the profit before tax and the value of the total assets.

d) Firm Size

Firm size measured as the natural logarithm of total asset. The firm size affected ability of the firm to bear the risks that arise due to various situations faced by the company (Andreas et al., 2015).

\section{Data Analysis}

The analysis method used in this research is a binary logistic regression. Binary logistic regression is an approach to create models like linear regression, but the dependent variable is dichotomous. The software used as an analytical tool is Statistic Product and Service Solutions (SPSS) version 20. Unlike linear regression, which demonstrates the degree of association between the dependent variable and independent variables, the logistic regression demonstrates odd ratio $(\mathrm{OR})$ that explain the probabilities of the outcome occurring $(P)$ divided by probabilities the outcome not occurring (P-1) (Hosmer \& Lemeshow, 2000:54).

\section{Results and Discussions}

\subsection{Descriptive Samples}

The descriptive sample of the variables used in this analysis is shown in Table 1.

Table 1

Descriptive samples

\begin{tabular}{lllllll}
\hline $\begin{array}{l}\text { Reporting } \\
\text { Stage }\end{array}$ & Code & $\begin{array}{l}\text { Industry } \\
\text { Type }\end{array}$ & Sample & $\begin{array}{l}\text { Reporting in } \\
\text { Sustainability } \\
\text { Report }\end{array}$ & Sample & Total Sample \\
\hline Defensive & 1 & High P & 209 & Yes & 49 & 327 \\
& 0 & Low P & 118 & No & 278 & \\
Proactive & 1 & High P & 187 & Yes & 81 & 317 \\
& 0 & Low P & 130 & No & 236 & 217 \\
Mimetic & 1 & High P & 123 & Yes & 50 & \\
& 0 & Low P & 94 & No & 167 & \\
\hline
\end{tabular}

Source: Data, analyzed 2018

Table 1 shows that 327 samples used as defensive reporting sampling, 317 samples used as proactive reporting sampling and 217 samples used as imitative reporting sampling in this research. Percentage of the high-profile firm in the sample was $63,37 \%$ in defensive, was $58,99 \%$ in proactive and 56, 68\% in mimetic reporting. There are $14,98 \%$ firm in defensive stage report their CSR, 25, 55\% in proactive reporting and 32,04\% in imitative reporting.

\subsection{Analysis of Logistic Regression}

Binary logistic regression is an analysis that used to analyze data like linear regression but with the dichotomous dependent variable. This analysis used to calculate the value of best fit of the model, which performed -2log Likelihood Ratio Test and Omnibus Test of Model Coefficients. The acceptance criteria of -2log Likelihood Ratio Test is the

Yani, N. P. R. K., Suprasto, H. B., Sari, M. M. R., \& Putri, I. G. A. M. A. D. (2019). Influence of industry type, profitability and size on corporate social responsibility reports isomorphism stage in Indonesia. International

Research Journal of Management, IT and Social Sciences, 6(4), 17-30. https://doi.org/10.21744/irjmis.v6n4.649 
model is fit if the value of $-2 \log$ Likelihood is smaller than $\chi^{2 \text { table }}$. The criteria of acceptance of Omnibus Test criteria is if the p-value of chi-square is smaller than determined significant level $(0,05)$. The value of the fit model in logistic regression is presented in Table 2 .

Table 2

Goodness fit of models

\begin{tabular}{|c|c|c|c|c|c|c|c|c|}
\hline \multirow{2}{*}{$\begin{array}{l}\text { Reporting } \\
\text { Stage }\end{array}$} & \multicolumn{4}{|c|}{-2Log likelihood } & \multicolumn{4}{|c|}{ Omnibus Test of Models Coefficient } \\
\hline & Model & & $\chi^{2 \text { Table }}$ & Result & Chi-square & Df & Sig. & Result \\
\hline Proactive & 241,043 & $<$ & 394,626 & Accepted & 35,235 & 3 & 0,000 & Accepted \\
\hline Normative & 267,284 & $<$ & 394,626 & Accepted & 93,030 & 3 & 0,000 & Accepted \\
\hline Imitative & 185,964 & $<$ & 248,048 & Accepted & 48,299 & 3 & 0,000 & Accepted \\
\hline
\end{tabular}

Source: Data, analyzed 2018

Based Table 2 we can see that the P-value of logistic regression models is smaller than 0,05 and chi-square model is smaller than the chi-square table. So we can conclude that the three models of logistic regression are fit to data. The result of hypothesis testing is presented in Table 3.

Table 3

Hypothesis test

\begin{tabular}{|c|c|c|c|c|c|c|}
\hline Reporting Stage & Hypothesis & Variable & Coeff. & P-Value & $\operatorname{Exp}(B)$ & Result \\
\hline \multirow[t]{3}{*}{ Defensive Stage } & $\mathrm{H} 1^{\mathrm{a}}$ & TI $->$ SR & $-0,730$ & 0,060 & 0,482 & Rejected \\
\hline & $\mathrm{H} 2^{\mathrm{a}}$ & ROA $->$ SR & 0,278 & 0,386 & 1,320 & Rejected \\
\hline & $\mathrm{H} 3^{\mathrm{a}}$ & SIZE -> SR & 0,663 & 0,000 & 1,940 & Accepted \\
\hline \multirow[t]{3}{*}{ Proactive Stage } & $\mathrm{H} 1^{\mathrm{b}}$ & $\mathrm{TI}->\mathrm{SR}$ & $-1,345$ & 0,000 & 0,261 & Accepted \\
\hline & $\mathrm{H} 2^{\mathrm{b}}$ & ROA $->$ SR & 5,556 & 0,000 & 261,387 & Accepted \\
\hline & $\mathrm{H} 3^{\mathrm{b}}$ & SIZE -> SR & 0,984 & 0,000 & 2,675 & Accepted \\
\hline \multirow[t]{3}{*}{ Imitative Stage } & $\mathrm{H} 1^{\mathrm{c}}$ & $\mathrm{TI}->\mathrm{SR}$ & $-1,387$ & 0,002 & 0,250 & Accepted \\
\hline & $\mathrm{H} 2^{\mathrm{c}}$ & ROA $->S R$ & 2,250 & 0,220 & 9,486 & Rejected \\
\hline & $\mathrm{H} 3^{\mathrm{c}}$ & SIZE -> SR & 0,896 & 0,000 & 2,450 & Accepted \\
\hline
\end{tabular}

Source: Data, analyzed 2018

\subsection{Hypotheses Discussion}

a) Industry Type has no Effect on CSR Reporting in Defensive Reporting

According to the result of the first hypothesis $\left(\mathrm{H} 1^{\mathrm{a}}\right)$ tested in this research, we found that P-Value $(0,060)$ is bigger than the determined significant level $(0,050)$. This result shows that industry type has no effect on CSR reporting in defensive reporting stage. This result supported the statement by Karina \& Yuyetta (2013) that there is no effect industry type on CSR reporting. Based on the coercive isomorphism, the firm motivates to disclose their CSR because of regulatory pressure. In Indonesia the Constitution Number 40 Years 2007 about limited liability companies; Constitution Number 25 Years 2007 about capital investment; and Constitution Number 39 Years 2009 about protection and environmental management requires the firm to do CSR activity and disclosure. The regulation is generally accepted by the firm in high-profile and low-profile.

b) Profitability has no Effect on CSR Reporting in Defensive Reporting

According to the result of the second hypothesis tested $\left(\mathrm{H} 2^{\mathrm{a}}\right)$ in this research, we found that the P-Value $(0,386)$ is bigger than the determined significant level $(0,050)$. This result shows that profitability has no effect on CSR reporting in defensive reporting stage. This result did not support the stakeholder theory that stated the higher profitability the more firm tend to disclose CSR. This result supported by Anggraini (2006); Kamil \& Herusetya (2012); Marfuah \& Cahyono (2011); Purwanto (2011) and Sembiring (2006) the profitability does not affect the firm tendency to disclose their CSR. This is because in coercive isomorphism the firm motivated by regulation (Amis et al., 2018). The firm aim to close the gap between the regulations and the firm's actual performance. 
c) Size influenced on CSR Reporting in Defensive Reporting

According to the result of the third hypothesis $\left(\mathrm{H}^{\mathrm{a}}{ }^{\mathrm{a}}\right.$ tested in this research, we found that P-Value $(0,000)$ is smaller than the determined significant level $(0,050)$ the coefficient is positive $(0,663)$ and the $\operatorname{Exp}(\mathrm{B})$ value of size is 1,940. The coefficient and $\operatorname{Exp}(\mathrm{B})$ value mean that the probabilities the firm with bigger size tends to disclose their CSR in sustainability report (2 times) than the firm with smaller size. This result shows that size affected on CSR reporting in defensive reporting stage. This result supported the statement by (Kamil \& Herusetya, 2012; Marfuah \& Cahyono, 2011; Purwanto, 2011; Sembiring, 2006) that state the size of the firm affected on CSR reporting. Based on the coercive isomorphism, the firm use CSR reporting as an effort to gain and maintain legitimation. This result supported the legitimacy theory that state the bigger size of the firm, the greater pressure they faced.

d) Industry Type influenced on CSR Reporting in Proactive Reporting

According to the result of hypothesis $\mathrm{H}^{\mathrm{b}}$ tested in this research, we found that P-Value $(0,000)$ is bigger than the determined significant level $(0,050)$ the coefficient is negative $(-1.345)$ and the $\operatorname{Exp}(\mathrm{B})$ value of industry type is 0,261. The coefficient and $\operatorname{Exp}(\mathrm{B})$ value mean that the probabilities of the firm categorized as high-profile to reporting CSR in sustainability are (0,02 times) lower than firm categorized as low profile. This result shows that industry type influenced on CSR reporting in proactive reporting stage. This results support the legitimation theory that stated the firm use CSR disclosure to maintain the firm legitimation. This result supported the argument that the industry type affected on CSR reporting (Andreas et al., 2015; Cahaya, 2012; Wang, et al., 2013). This result also supports Shabana et al., (2016) that state the industry type affected on CSR reporting in proactive reporting stage. Industry type influenced in proactive reporting stage because in of Indonesian Government Regulation Number 47 Years 2012 state that the firm must plan their CSR fund and activity in general meeting of shareholder (RUPS). This regulation makes the firm to manage their CSR more flexible based on their industry profile and adjust it according to the institutional pressure.

e) Profitability influenced on CSR Reporting in Proactive Reporting

According to the result of hypothesis $\mathrm{H} 2^{\mathrm{b}}$ tested in this research, we found that the P-Value $(0,000)$ is smaller than the determined significant level $(0,050)$ the coefficient is positive $(5,556)$ and the $\operatorname{Exp}(\mathrm{B})$ value of profitability is 267,387. The coefficient and $\operatorname{Exp}(B)$ value mean that probabilities of the firm that have higher profitability will have a higher tendency (267 times) to disclose their CSR in sustainability report. This result shows that profitability has no effect on CSR reporting in defensive reporting stage. This result support stakeholder theory that state the higher profitability the more firm tended to disclose CSR to show that the firm in strong financial and competition condition. This result supports the argument Sirait \& Bangun (2013) that state the profitability influenced on CSR reporting and Sawaka K \& Putri (2016) that state CSR could increase the number customer then also increase the profitability.

f) Size influenced on CSR Reporting in Proactive Reporting

According to the result of hypothesis $\mathrm{H} 3^{\mathrm{b}}$ tested in this research, we found that $\mathrm{P}$-Value $(0,000)$ is smaller than the determined significant level $(0,050)$ the coefficient is positive $(0,984)$ and the $\operatorname{Exp}(\mathrm{B})$ value of size is 2,675 . The coefficient and $\operatorname{Exp}(B)$ value mean that the probability the firm with bigger size tend to disclose their CSR in sustainability report (2,7 times) than the firm with smaller size. This result shows that size affected on CSR reporting in proactive reporting stage. This result supported the legitimation theory and argument by Andreas $e t$ al., (2015); Aulia \& Agustina (2015); Bawono \& Haryanto (2015); Karina \& Yuyetta (2013); Sirait \& Bangun (2013); Wang et al. (2013); and Wulansari \& Priyadi (2015). Normative isomorphism explains that the CSR reporting is used to avoid the normative sanction from the community. The bigger size of the firm the more attention from the community so disclosing CSR will legitimate their operational activity. The presence of Government Regulation Number 47 Years 2012 about Social Responsibility and Environment make the firm must plan and discuss their CSR activity in general shareholder meeting (RUPS) to the specific goals in the community. The firm realized the benefits of CSR reporting is more than the cost of CSR activity (Shabana et al., 2016).

g) Industry Type influenced on CSR Reporting in Imitative Reporting

According to the result of hypothesis $\mathrm{H}^{\mathrm{c}}$ tested in this research, we found that $\mathrm{P}$-Value $(0,002)$ is bigger than the determined significant level $(0,050)$ the coefficient is negative $(-1.387)$ and the $\operatorname{Exp}(\mathrm{B})$ value of industry type is 0,261 . The coefficient and $\operatorname{Exp}(\mathrm{B})$ value mean that the probabilities of firm categorized as high-profile to reporting

Yani, N. P. R. K., Suprasto, H. B., Sari, M. M. R., \& Putri, I. G. A. M. A. D. (2019). Influence of industry type,

profitability and size on corporate social responsibility reports isomorphism stage in Indonesia. International

Research Journal of Management, IT and Social Sciences, 6(4), 17-30. https://doi.org/10.21744/irjmis.v6n4.649 
CSR in sustainability is $(0,25$ times) lower than firm categorized as low-profile. This result shows that industry type influenced on CSR reporting in imitative reporting stage. This result supported the legitimation theory that stated the firm use CSR disclosure to maintain the firm legitimation. This result supported the argument that the industry type affected on CSR reporting (Andreas et al., 2015; Ni Made Windya Apriyanti \& Budiasih, 2016; Pratiwi \& Sari, 2016). In the mimetic isomorphism stage, the firm tends to imitate the other firm's CSR practice. Cahaya (2012) state that in the mimetic mechanism, the firm in Indonesia uses CSR program conformable with another firm in the specific industry domestically and abroad.

\section{h) Profitability has no Effect on CSR Reporting in Imitative Reporting}

According to the result of the hypothesis $\mathrm{H} 2^{c}$ tested in this research, we found that the P-Value $(0,220)$ is bigger than the determined significant level $(0,050)$. This result shows that profitability has no effect on CSR reporting in imitative reporting stage. This result did not support the stakeholder theory that state the higher profitability the more firm tends to disclose their CSR. This result supported the argument by (Anggraini, 2006; Kamil \& Herusetya, 2012; Marfuah \& Cahyono, 2011; Purwanto, 2011; Sembiring, 2006) that state the profitability has no effect on CSR disclosure. This result also supports mimetic isomorphism that state the firm tend to imitate the other firm's practice in order to gain some success. They don't consider their profitability to gain the same success as the other firm in the same industry.

i) Size influenced on CSR Reporting in Imitative Reporting

According to the result of hypothesis $\mathrm{H}^{\mathrm{c}}$ tested in this research, we found that P-Value $(0,000)$ is smaller than the determined significant level $(0,050)$ the coefficient is positive $(0,984)$ and the $\operatorname{Exp}(\mathrm{B})$ value of size is 2,675 . The coefficient and $\operatorname{Exp}(\mathrm{B})$ value mean that the probabilities the firm with bigger size tends to disclose their CSR in sustainability report (2,7 times) than the firm with smaller size. This result shows that size affected on CSR reporting in proactive reporting stage. Based on the legitimation theory, the big firm tends to disclose and report their CSR information more than the smaller firm to reduce negative's public spotlight. This result is consistent with Andreas et al., (2015); Bawono \& Haryanto (2015); and Tan et al., (2016) that state the size has a positive influence on CSR disclosure. This result also supports the finding of Shabana et al., (2016) that state the size influenced on CSR reporting in imitative reporting stage. Mimetic isomorphism state that the firm motivated to disclose their CSR by imitating other firm's practice that considered as the best and the most valuable because there is no more specific regulation. The manager tends to pattern their firm similar to the other firm in the same environment that considered as the success one (DiMaggio \& Powell, 1983).

\section{Conclusion}

According to the analysis conducted in this research concluded that: (1) only size affected on CSR reporting in the defensive reporting stage; (2) the industry type, profitability, and size affected on CSR reporting in the proactive reporting stage; (3) the industry type and size affected on the CSR reporting in the proactive reporting stage.

In the defensive reporting stage, the firm tends to disclose their CSR to maintain legitimation and their sustainability. For the defensive stage, we predict that the industry type, profitability, and size will increase the likelihood of CSR reporting. We found that only size affected on CSR reporting in the defensive stage. The regulation has strong influences to motivate the firm to disclose CSR so they didn't consider their industry type and their financial performance. Even firms that doesn't have negative event disclose CSR report as a defense against negative public perceptions (Shabana et al., 2016). They tend to defend and maintain their sustainability.

Firms begin to assess the story they can tell if they publish CSR reports and those that are strong in their CSR performance proactively choose to publish CSR reports from goal-oriented perspective leading to the proactive reporting stage (Shabana et al., 2016). In the formative stage, the firm tends to disclose their CSR to avoid the normative sanction and negative perception from the stakeholder. The firm wants to show that they in good social and environmental performance. In this stage the variables industry type, profitability, and size affected on CSR reporting. Based the Government Regulation Number 47 Years 2012 the firm plan and consider their CSR plan and activity in general meeting shareholder to integrating their CSR performance and the firm goals specifically. This is driving the CSR implementation efficiently.

As more firms publish CSR report to achieve their goals, the ratio of reporting to non-reporting begins to shift (Shabana et al., 2016). The more firm discloses their CSR report, the greater pressure will be arises to another firm to 
copy social innovation that had become widespread. In the imitative reporting, the result shows that the industry type and size affected on CSR reporting. The firm tends to imitate the firm that considered has best CSR reporting practices in the same industry to gain the same success.

The general result shows that only size consistently affected on CSR reporting in Indonesia, meanwhile industry type and profitability show mix results. Government regulation seems like a powerful institutional pressure that leads the firm's CSR reporting practice. The firms in Indonesia tend to be sensitive in changes in CSR regulation. This result in accordance with a survey of KPMG (2015) that state Indonesia is a country with a corporate responsibility reporting rate of 90 percent or above have a mandatory requirement.

\section{Research Limitation and Suggestion}

Our analysis is of Kompas100 index firm, using models that reflect the evolution of CSR reporting driven by Indonesian government intervention. The study result is finite to Indonesian country's condition. We suggest for future research is to adjust the regulation each country. The research limitation is impossible to differentiate between the firm that conveys the actual performance and the firm that intend to make a positive impression of poor performance because of variation in the content and quality of the published report are not reflected in the dependent variable.

This research has implications for a number of interest parties, such as government and firms. The government is expected to consider this research result to issues of new regulation about CSR reporting to increase the firm's quality social and environmental reporting. The firm is expected to maintain its CSR activity and reporting to their business and social sustainability.

Conflict of interest statement and funding sources

The authors declared that they have no competing interest.

Statement of authorship

The authors have a responsibility for the conception and design of the study. The authors have approved the final article.

\section{Acknowledgments}

The authors would like to thank the Editor of IRJMIS for their valuable time, support, and advice in completing the current study.

Yani, N. P. R. K., Suprasto, H. B., Sari, M. M. R., \& Putri, I. G. A. M. A. D. (2019). Influence of industry type, profitability and size on corporate social responsibility reports isomorphism stage in Indonesia. International Research Journal of Management, IT and Social Sciences, 6(4), 17-30. https://doi.org/10.21744/irjmis.v6n4.649 
References

Anggraini, F. R. R. (2006). Pengungkapan informasi sosial dan faktor-faktor yang mempengaruhi pengungkapan informasi sosial dalam laporan keuangan tahunan (Studi empiris pada perusahaan-perusahaan yang terdaftar Bursa Efek Jakarta). Simposium Nasional Akuntansi, 9, 23-26.

Apriyanti, N. M. W., \& Budiasih, I. G. A. N. (2016). Profitabilitas Dan Corporate Social Responsibility Pada Perusahaan High Dan Low Profile. E-Jurnal Akuntansi, 977-1004.

Apriyanti, N. M. W., \& Budiasih, I. G. A. N. (2016). Profitabilitas Dan Corporate Social Responsibility Pada Perusahaan High Dan Low Profile. E-Jurnal Akuntansi, 977-1004.

Aulia, F. Z. (2015). Pengaruh Karakteristik Perusahaan, Kinerja Lingkungan, dan Liputan Media terhadap Environmental Disclosure (Doctoral dissertation, Universitas Negeri Semarang).

Aghara, V. N. O., Nwaizugbo, I. C., Oparah, P. C., \& Ifeanyichukwu, C. D. (2018). Sales promotion as a leverage strategy for improving sales and profitability in alcohol beverage industry. International Research Journal of Management, IT and Social Sciences, 5(4), 18-25. https://doi.org/10.21744/irjmis.v5n4.245

Bawono, A. A. K., \& Haryanto, H. (2015). Pengaruh ukuran perusahaan, leverage, profitabilitas, cakupan operasional perusahaan, dan sertifikasi iso 14001 terhadap pengungkapan corporate social responsibility (Studi pada Perusahaan Manufaktur yang Terdaftar di BEI Tahun 2012-2013) (Doctoral dissertation, Fakultas Ekonomika dan Bisnis).

Beddewela, E., \& Fairbrass, J. (2016). Seeking legitimacy through CSR: Institutional pressures and corporate responses of multinationals in Sri Lanka. Journal of business ethics, 136(3), 503-522. https://doi.org/10.1007/s10551-014-2478-z

Cahaya, F. R. (2016). Health and Safety Disclosures in Indonesia: A CSR Convergence Strategy. JESI (Jurnal Ekonomi Syariah Indonesia), 2(2), 143-154.

Dewi, I. G. A. A. O., \& Dewi, I. G. A. A. P. (2017). Corporate social responsibility, green banking, and going concern on banking company in Indonesia stock exchange. International Journal of Social Sciences and Humanities, 1(3), 118-134. https://doi.org/10.29332/ijssh.v1n3.65

DiMaggio, P. J., \& Powell, W. W. (1983). The iron cage revisited: Institutional isomorphism and collective rationality in organizational fields. American sociological review, 147-160. https://doi.org/10.1007/10.2307/2095101

Donleavy, G. (2016). An Introduction to Accounting Theory.[Documento en Línea]. Extraído de https://bookboon. com/en/an-introduction-to-accountingtheory-ebook consulta, 15(06), 2018.

Fisher, V. E. (2016). A study of how CSR rankings are affected in a globalized economy. McNair Scholars Research Journal, 9(1), 7.

Frumkin, P., \& Galaskiewicz, J. (2004). Institutional isomorphism and public sector organizations. Journal of public administration research and theory, 14(3), 283-307. https://doi.org/10.1093/jopart/muh028

Hadjoh, R. A., \& Sukartha, I. M. (2013). Pengaruh Ukuran Perusahaan, Kinerja Keuangan dan Eksposur Media pada Pengungkapan Informasi Lingkungan. E-Jurnal Akuntansi, 1-18.

Hosmer, D. W., \& Lemeshow, S. (2000). Applied Logistic Regression. John Wiley \& Sons. New York.

Hamidu, Ahmad, Md Haron, and Azlan Amran. "Corporate Social Responsibility: A Review on definitions, core characteristics and theoretical perspectives." Mediterranean Journal of Social Sciences 6.4 (2015): 83-95.

Indonesian Constitution No. 40 (2007). Indonesia.

Indonesian Financial Service. Indonesian Financial Authority Service Number 29/POJK.04/2016 (2016). https://doi.org/https://www.ojk.go.id/id/kanal/pasar-modal/regulasi/peraturan-ojk/Documents/Pages/POJKLaporan-Tahunan-Emiten-Perusahaan-Publik/POJK-Laporan-Tahunan.pdf

Indonesian Financial Service. (2016b). Infografis Lembaga Jasa Keuangan dan Emiten Penerbit Sustainability Report. Retrieved April 23, 2018, from https://www.ojk.go.id/sustainable-finance/id/publikasi/riset-danstatistik/Pages/Sustainability-Report-bagi-Lembaga-Jasa-Keuangan-dan-Emiten.aspx

Indonesian Government Regulation No. 47 (2012). Retrieved from http://hukum.unsrat.ac.id/pp/pp2012_47.pdf

Ismail, I. K., \& Haddaw, A. A. (2014). The impact of the theory of legitimacy on the disclosure of organizations in Jordan using a linear regression model. Journal of Business and Management, 6(16), 190-196.

Anggiyani, S. W., \& Yanto, H. (2016). Determinan pengungkapan sustainability report pada perusahaan yang terdaftar di Bursa Efek Indonesia. Accounting Analysis Journal, 5(2), 1-10.

Kamil, A., \& Herusetya, A. (2012). Pengaruh karakteristik perusahaan terhadap luas pengungkapan kegiatan corporate social responsibility. Media Riset Akuntansi, 2(1).

Karina, L. A. D., \& Yuyetta, E. N. A. (2013). Analisis Faktor-Faktor yang Mempengaruhi Pengungkapan CSR (Studi Empiris pada Perusahaan Manufaktur yang Terdaftar di Bursa Efek Indonesia Tahun 2011) (Doctoral dissertation, 
Fakultas Ekonomika dan Bisnis).

Kastutisari, S. (2013). Pengaruh Pengungkapan Corporate Social Responsibility (CSR) Terhadap Abnormal Return(Doctoral dissertation, STIE Perbanas Surabaya).

Kontan.co.id. (2011). Dari 438 Emiten, hanya 25 Perusahaan yang Membuat Laporan Berkelanjutan. Retrieved April 3, 2019, from http://investasi.kontan.co.id/news/dari-438-emiten-hanya-25-perusahaan-yang-membuat-laporankeberlanjutan

King, A., \& Bartels, W. (2015). Currents of change: the KPMG survey of corporate responsibility reporting 2015. Netherlands: KPMG.

Linzan, Ángel R. A., Sauvanell, Ángel L. B., \& Parra, M. I. F. (2018). Exergoeconomic and ecological efficiency analysis of steam generation system in ecuadorian tuna industry. International Research Journal of Engineering, IT \& Scientific Research, 4(2), 52-62.

Marfuah, M., \& Cahyono, Y. D. (2011). Karakteristik perusahaan dan pengungkapan tanggung jawab sosial. Indonesian Journal of Accounting and Auditing, 15(1).

Margaretha, F., \& Rachmawati, B. (2016). The Effect of Corporate Social Responsibility to Financial Performance of Company in Indonesia. OIDA International Journal of Sustainable Development, 9(04), 11-18.

Martínez-Ferrero, J., \& García-Sánchez, I. M. (2017). Coercive, normative and mimetic isomorphism as determinants of the voluntary assurance of sustainability reports. International Business Review, 26(1), 102-118.

Mair, J., Amis, J., \& Munir, K. (2017). Institutions and Economic Inequality.

Matten, D., \& Moon, J. (2008). "Implicit" and "explicit" CSR: A conceptual framework for a comparative understanding of corporate social responsibility. Academy of management Review, 33(2), 404-424. https://doi.org/10.5465/AMR.2008.31193458

Maulana, F., \& Yuyetta, N. A. (2014). Pengaruh Karakteristik Perusahaan Terhadap Pengungkapan Corporate Social Responsibility (CSR). Diponegoro Journal of Accounting, 3(2), 1-14. Retrieved from http://ejournals1.undip.ac.id/index.php/accounting

Misztal, A., \& Jasiulewicz-Kaczmarek, M. (2014). Environmental issues of the corporate social responsibility. Management, 18(1), 58-70. https://doi.org/10.2478/manment-2014-0005

Manteiro, M. C. B., \& Kabu, E. (2019). Model of creative economic development for micro, small and medium-sized culinary industries in Kupang City Indonesia. International Journal of Social Sciences and Humanities, 3(1), 143152. https://doi.org/10.29332/ijssh.v3n1.275

Nuryani, N. N. J., Satrawan, D. P. R., Gorda, A. A. N. O. S., \& Martini, L. K. B. (2018). Influence of human capital, social capital, economic capital towards financial performance \& corporate social responsibility. International Journal of Social Sciences and Humanities, 2(2), 65-76. https://doi.org/10.29332/ijssh.v2n2.128

Patten, D. M., \& Zhao, N. (2014, June). Standalone CSR reporting by US retail companies. In Accounting Forum (Vol. 38, No. 2, pp. 132-144). Taylor \& Francis. https://doi.org/10.1016/j.accfor.2014.01.002

Pratiwi, P. C., \& Sari, V. F. (2018). Pengaruh Tipe Industri, Media Exposure dan Profitabilitas terhadap Carbon Emission Disclosure. Wahana Riset Akuntansi, 4(2).

Purwanto, A. (2011). Pengaruh tipe industri, ukuran perusahaan, profitabilitas, terhadap corporate social responsibility. Jurnal Akuntansi dan Auditing, 8(1), 12-29.

Roszkowska-Menkes, M., \& Aluchna, M. (2017). Institutional isomorphism and corporate social responsibility: towards a conceptual model. Journal of Positive Management, 8(2), 3-16. https://doi.org/10.12775/JPM.2017.007

Sawaka K, I. G. N. H., \& Putri, I. G. A. M. (2016). Analisis Pengungkapan dan Dampak Penerapan Corporate Social Responsibility di PT. Bank Pembangunan Daerah Bali. E-Jurnal Akuntansi Universitas Udayana, 16(2), 837-864.

Sembiring, E. R. (2006). Karakteristik perusahaan dan pengungkapan tanggung jawab sosial: study empiris pada perusahaan yang tercatat di Bursa Efek Jakarta. MAKSI, 6.

Shabana, K. M., Buchholtz, A. K., \& Carroll, A. B. (2017). The institutionalization of corporate social responsibility reporting. Business \& Society, 56(8), 1107-1135. https://doi.org/10.1177/0007650316628177

Suardana, I. B. R., Astawa, I. N. D., \& Martini, L. K. B. (2018). Influential factors towards return on assets and profit change. International Journal of Social Sciences and Humanities, 2(1), $105-116$. https://doi.org/10.29332/ijssh.v2n1.100

Shadnam, M., \& Lawrence, T. B. (2011). Understanding widespread misconduct in organizations: An institutional theory of moral collapse. Business Ethics Quarterly, 21(3), 379-407. https://doi.org/10.5840/beq201121324

Sirait, A. Y. M., \& Bangun, P. (2016). Analisis faktor-faktor yang mempengaruhi pengungkapan corporate social responsibility (csr) studi empiris pada perusahaan yang listed di bei. Akuntansi Krida Wacana, 13(02).

Suchman, M. C. (1995). Managing legitimacy: Strategic and institutional approaches. Academy of management

Yani, N. P. R. K., Suprasto, H. B., Sari, M. M. R., \& Putri, I. G. A. M. A. D. (2019). Influence of industry type, profitability and size on corporate social responsibility reports isomorphism stage in Indonesia. International Research Journal of Management, IT and Social Sciences, 6(4), 17-30. https://doi.org/10.21744/irjmis.v6n4.649 
review, 20(3), 571-610. https://doi.org/10.5465/AMR.1995.9508080331

Susanto, P. B., \& Subekti, I. (2012). Pengaruh corporate social responsibility dan good corporate governance terhadap nilai perusahaan (Pada perusahaan yang terdaftar Di Bursa Efek Indonesia). Jurnal Ilmiah Mahasiswa FEB, 1(2).

Tan, A., Benni, D., \& Liani, W. (2016). Determinants of corporate social responsibility disclosure and investor reaction. International Journal of Economics and Financial Issues, 6(4S).

Wang, H., Tong, L., Takeuchi, R., \& George, G. (2016). Corporate social responsibility: An overview and new research directions: Thematic issue on corporate social responsibility. https://doi.org/10.5465/amj.2016.5001

Wang, J., Song, L., \& Yao, S. (2013). The determinants of corporate social responsibility disclosure: evidence from China. Journal of Applied Business Research, 29(6), 1833.

Widyastari, N. K. W., \& Sari, M. M. R. (2018). Pengaruh Ukuran Perusahaan , Proporsi Dewan Komisaris Independen , dan Kepemilikan Asing Pada Pengungkapan Corporate Social Responsibility Fakultas Ekonomi dan Bisnis Universitas Udayana ( Unud ), Bali , Indonesia Fakultas Ekonomi dan Bisnis Universitas U. E-Jurnal Akuntansi Univesitas Udayana, 22(2), 1826-1856.

Winata, V. (2014). Corporate Social and Environmental Reporting: Kasus Mimetic Isomorphism Pada Perusahaan Go Public di Indonesia Periode 2011-2013.

Wulandari, I. A., \& Herkulanus, B. S. (2015). Konservatisme Akuntansi, Good Corporate Governance dan Pengungkapan Corporate Social Responsibility Pada Earnings Response Coefficient. E-Jurnal Akuntansi, 173-190.

Wulansari, D. D., \& Priyadi, M. P. (2015). Faktor-faktor yang mempengaruhi kebijakan pengungkapan tanggung jawab sosial dan lingkungan. Jurnal Ilmu \& Riset Akuntansi, 4(12), 1-15.

Yanti, N. M. Y. W. A., \& Dwirandra, A. (2019). The effect of profitability in income smoothing practice with good corporate governance and dividend of payout ratio as a moderation variable. International Research Journal of Management, IT and Social Sciences, 6(2), 12-21. https://doi.org/10.21744/irjmis.v6n2.601 